Magdalena KACPERSKA

Uniwersytet im. Adama Mickiewicza, Poznań

\title{
Wpływ rozszerzenia wschodniego na rynek pracy $w$ UE
}

R ozszerzenie Unii Europejskiej o kraje Europy Środkowo-Wschodniej tegracji europejskiej nie przyjmowano jeszcze aż tak wielu państw jednocześnie. Do 15 państw tworzących UE dnia 1 maja 2004 r. dołączyło 10 nowych, tworząc ugrupowanie liczące 25 państw.

Proces ten dokonał się na podstawie Art. 0 Traktatu z Maastricht, w myśl którego „każde państwo europejskie może ubiegać się o status członka Unii’. Powołując się na ten zapis, wnioski zostały złożone przez: Węgry (31 marca 1994 r.), Polskę (8 kwietnia 1994 r.), Rumunię (22 czerwca 1995 r.), Słowację (27 czerwca 1995 r.), Łotwę (13 października 1995 r.), Estonię (24 listopada 1995 r.), Litwę (8 grudnia 1995 r.), Bułgarię (14 grudnia 1995 r.), Czechy (17 stycznia 1996 r.) i Słowenię (10 czerwca 1996 r.). Poza krajami Europy Środkowo-Wschodniej wnioski złożyły także Cypr i Malta (lipiec 1990) ${ }^{1}$. Pierwsza grupa kandydujących państw, czyli: Czechy, Estonia, Polska, Słowenia, Węgry oraz Cypr, rozpoczęła negocjacje akcesyjne 31 marca 1998 r., druga zaś: Bułgaria, Litwa, Łotwa, Rumunia, Słowacja oraz Malta, 15 lutego 2000 r. Spośród tej dwunastki negocjacje zakończyło w dniu 13 grudnia 2002 r., podczas spotkania Rady Europejskiej w Kopenhadze, dziesięć państw: Czechy, Estonia, Litwa, Łotwa, Polska, Słowacja, Słowenia i Węgry oraz Cypr i Malta ${ }^{2}$.

Wielokrotnie podkreśla się, jak ogromne znaczenie dla funkcjonowania Wspólnoty miały poszczególne jej rozszerzenia. Przyjmowane państwa charakteryzował zróżnicowany poziom rozwoju gospodarczego oraz odmienna struktura gospodarki, co powodowało konieczność podjęcia

1 Jednak Malta zamroziła stosunki z UE w 1996 r., a następnie reaktywowała swój wniosek we wrześniu 1998 r.

2 Rozszerzanie Unii Europejskiej na Wschód, „ABC Unii Europejskiej”, Przedstawicielstwo Komisji Europejskiej w Polsce, Warszawa, kwiecień 2003. 
działań na rzecz ich wyrównania oraz zbliżenia do wskaźników występujących wśród dotychczasowych członków WE. Biorąc zatem pod uwagę specyficzne cechy gospodarek nowoprzyjętych państw należy stwierdzić, iż proces zbliżania się do poziomu rozwoju państw przyjmujących będzie długi i żmudny oraz będzie wymagał radykalnych i konsekwentnych działań zarówno ze strony całej Unii, jak i ze strony poszczególnych państw. Rozszerzenie stało się zatem ważnym impulsem do przeprowadzenia reform, m.in. wspólnej polityki rolnej (WPR) i funduszy strukturalnych, od których w dużej mierze zależały i zależeć będą koszty poszerzenia dla starych członków. Przy założeniu braku reform wspólnej polityki rolnej oraz pozostawieniu obecnych zasad przyznawania pomocy strukturalnej na lata 2007-2013 i utrzymaniu poziomu wsparcia dla dotychczasowych członków na takim samym poziomie, jak założony w roku 2006, koszty rozszerzenia wzrosną z $0,03 \%$ PKB rozszerzonej Unii w 2004 r. do 0,23\% w roku 2013. Jeśli natomiast powyższe reformy zostaną przeprowadzone, koszty te wzrosną do roku 2013 do $0,18 \% \mathrm{PKB}^{3}$.

Jednak, mimo ogromnego znaczenia przystąpienia nowych państw do Unii, nadal główne wskaźniki gospodarcze i w zakresie rynku pracy będą determinowane sytuacją w państwach „starej” Unii, które stanowią ponad $80 \%$ populacji rozszerzonej struktury. W efekcie rozszerzenia bowiem populacja wzrośnie o $20 \%$, podczas gdy całkowity PKB zwiększy się o ok. $9 \%$, zaś całkowite zatrudnienie o ok. $18 \%{ }^{4}$.

Należy podkreślić, iż mimo wielu obaw ze strony dotychczasowych oraz nowych członków Unii, rozszerzenie będzie miało w długookresowej perspektywie korzystny wpływ na rozwój gospodarczy zarówno krajów przyjmujących, jak i przyjętych. Nowym członkom pomoże nadrobić dystans w rozwoju gospodarczym i poziomie życia, starym zaś da impuls do reform, których przeprowadzenie jest konieczne, by realizować założenia strategii lizbońskiej ${ }^{5}$.

Największe obawy wśród dotychczasowych członków wzbudzają kwestie związane z migracjami, dumpingiem socjalnym oraz koniecznymi do wdrożenia reformami, wymuszonymi przystapieniem nowych państw. Jedną z najczęściej podnoszonych kwestii przed rozszerzeniem była spodzie-

3 Koniunktura gospodarcza na świecie 2002-2004, Rządowe Centrum Studiów Strategicznych, Warszawa 2003, s. 27-29.

${ }^{4}$ Employment in Europe 2003. Recent Trends and Prospects, European Commission, Directorate-General for Employment and Social Affairs, wrzesień 2003, s. 43-44.

${ }^{5}$ Koniunktura gospodarcza..., op. cit., s. 27-28. 
wana fala migracji z krajów Europy Środkowo-Wschodniej powodowana znacznymi różnicami (większymi niż podczas poprzednich rozszerzeń) w poziomie dochodów w tych krajach w porównaniu do krajów unijnej 15. Dochody na osobę w krajach EŚiW w porównaniu z dochodami dotychczasowych członków miały się jak jeden do dziesięciu według kursu walutowego w 2000 r. oraz jak jeden do trzech pod względem parytetu siły nabywczej ${ }^{6}$. W obliczu powyższego oraz innych czynników należało oczekiwać pewnego nasilenia procesów migracyjnych, jednak w rzeczywistości nie przybrały one charakteru masowego. Ponadto migruje przede wszystkim najbardziej mobilna, czyli młoda siła robocza, co daje nadzieję na poprawę i rozwiązanie problemu, z jakim boryka się ,stara” Unia, problemu starzejącego się społeczeństwa. Migracja nie będzie miała w dłuższej perspektywie istotnego znaczenia, gdyż jej skalę będzie ograniczało stopniowe podnoszenie płac i poziomu życia w krajach EŚiW, będące wynikiem znacznie szybszego tempa wzrostu gospodarczego, aniżeli w UE-15 oraz dostrzeżenie przez najbardziej mobilne grupy szans i możliwości rozwoju we własnym kraju, które wzrosną w efekcie pozytywnego wpływu poszerzenia. Analizując potencjał migracyjny należy także wziąć pod uwagę wielkość i strukturę bezrobocia w poszczególnych krajach. Jak wspomniano, najbardziej mobilną siłę roboczą stanowią ludzie młodzi, którzy nie mogą znaleźć pracy we własnym kraju. Choć bezrobocie młodzieży jest istotnym czynnikiem skłaniającym tę grupę do podjęcia decyzji o migracji zarobkowej, to jednak nie jedynym, a istotne znaczenie odgrywają tu także inne czynniki, takie jak znajomość języków, odmienność kulturowa oraz koszty związane z rozłąką z rodziną i najbliższym otoczeniem.

Przewiduje się, iż migracja wyniesie ok. 300000 rocznie w pierwszych latach i będzie ulegała zmniejszeniu do mniej niż 50000 rocznie w ciągu następnej dekady ${ }^{7}$. Analizy wskazują, że w 2010 r. do państw „starej” Unii przybędzie jedynie 150 tys. obywateli państw rozszerzenia wschodniego, a 30 lat po wprowadzeniu swobody przemieszczania się osiagnięta zostanie pewnego rodzaju równowaga liczby przyjazdów i wyjazdów. Liczba obywateli tych państw wyniesie w całej Unii 3,9 mln, co

6 Wplyw poszerzenia Unii Europejskiej o kraje Europy Środkowej i Wschodniej na zatrudnienie $i$ rynek pracy $w$ krajach czlonkowskich Unii, streszczenie raportu przygotowanego na prośbę Dyrekcji Generalnej ds. Zatrudnienia i Spraw Społecznych Komisji Europejskiej, Komitet Integracji Europejskiej, Berlin-Mediolan 2000, s. 96.

7 Report of the High Level Group on the future of social policy in an enlarged European Union, European Commission, maj 2004, s. 12. 
stanowić będzie 1,1\% ogólnej liczby ludności. Rozkład migracji nie będzie jednak równomierny, a największy odsetek migrujących przyjmą Niemcy, gdzie liczba przyjezdnych może sięgnąć $2,5 \mathrm{mln}$, czyli 3,5\% ludności tego kraju. Podobnie ocenia wpływ poszerzenia na ruchy migracyjne Komisja Europejska, która w przedstawionym w 2000 r. państwom kandydującym stanowisku stwierdziła, iż rozszerzenie nie wpłynie dramatycznie na wzrost migracji, a jej konsekwencje dla rynku pracy będą ograniczone. Komisja zaznaczyła także, iż obawy związane z masowym napływem ludności z Portugalii i Hiszpanii nie potwierdziły się, a długi okres przejściowy nie zdał egzaminu ${ }^{8}$. W obliczu powyższych rozważań podkreślenia wymaga bezzasadność stosowania ograniczeń w dostępie obywateli nowych członków do rynku pracy takich państw, jak Niemcy czy Austria. Dwa lata po rozszerzeniu Komisja Europejska przedstawiła raport dotyczący wpływu integracji na rynki pracy poszczególnych państw, które musiały zdecydować o utrzymaniu ograniczeń w dostępie do swoich rynków bądź też o ich zniesieniu i stosowaniu unijnej zasady swobody przepływu bez ograniczeń. Jeśli dane państwo wskaże poważne zakłócenia na wewnętrznym rynku pracy będzie mogło kontynuować restrykcyjne nastawienie aż do roku $2011^{9}$ (7 lat od 2004 r., czyli maksymalny okres przejściowy w tym obszarze).

Kolejna obawa związana $\mathrm{z}$ otwieraniem rynków pracy dla nowych państw to tzw. dumping socjalny, czyli mniejsze wymagania związane z warunkami pracy przy zbliżonym poziomie kwalifikacji, które moga wywołać presję na obniżanie płac i standardów socjalnych ${ }^{10}$. Obawa ta wydaje się być uzasadniona, zważywszy, że średni poziom dochodów w nowych krajach członkowskich stanowi mniej niż połowę średniego poziomu dla dawnej unijnej 15, a ponadto poziom produktywności (na jednego zatrudnionego) kształtuje się na poziomie 53,6\% jeśli przyjmiemy, że produktywność w Unii równa się $100^{11}$. Jednak we wszystkich państwach EŚiW w ciagu ostatniej dekady obserwuje się znaczący wzrost płac, będący rezultatem, znacznie większego niż w państwach UE-15,

8 Rozszerzenie Unii Europejskiej na Wschód - konsekwencje dla dobrobytu i zatrudnienia w Europie, opinia o Raporcie Fundacji F. Eberta, Die Osterweiterung der Europaischen Union Konsequenzen fur Wohlstand und Beschaftigung in Europa, s. $67-68$.

9 Report of the High Level Group..., op. cit., s. 12.

10 Koniunktura gospodarcza..., op. cit., s. 29.

11 Commission Recommendation on the 2004 update of the Broad Guidelines of the Economic Policies of the Member States and the Community (for the 2003-2005 period), Commission of the European Communities, Bruksela 2004, s. 5-6. 
wzrostu gospodarczego. Tendencja będzie się nadal utrzymywała i płace w nowych krajach członkowskich będą rosły szybciej, aniżeli średnio w państwach przyjmujących ${ }^{12}$.

Rozszerzenie Wschodnie było zupełnie inne od rozszerzenia Południowego m.in. ze względu na rozziew w poziomie dochodu per capita, a także ze względu na stopień integracji tych krajów z gospodarką europejska. Znaczącemu rozziewowi w dochodach towarzyszy w tym przypad$\mathrm{ku}$, inaczej niż w rozszerzeniu Południowym, wysoki stopień integracji gospodarczej ${ }^{13}$. Stosunki handlowe między UE a krajami EŚiW zwiększyły się znacznie, w wyniku liberalizacji zasad handlowych, już w okresach przedakcesyjnych, poprzedzających pełną integrację. Charakterystycznym dla wymiany towarowej między dotychczasowymi członkami, a nowymi krajami było, iż kraje UE-15 eksportują do EŚiW towary o wielkim udziale kapitału i dużym „nasyceniu” kwalifikowaną siłą roboczą, natomiast importują dobra, które mają duży udział czynnika pracy (pracochłonne). Należy podkreślić, iż otwarcie rynków większości krajów EŚiW już w połowie lat 90. przyczyniło się do tzw. importu bezrobocia, czyli znacznego wzrostu importu z krajów unijnych, co przy niskiej konkurencyjności rodzimych produktów powodowało spadek eksportu i upadanie kolejnych przedsiębiorstw, a przez to wzrost bezrobocia. Analizy dotyczące wkładu pracy zawartego w towarach eksportowanych do krajów EŚiW, wskazują, że handel ten kreuje w krajach UE-15 kilkadziesiąt tysięcy miejsc pracy. Jednak obecne tendencje w zakresie obrotów handlowych pozwalają stwierdzić, iż nowe państwa członkowskie zyskają znacznie więcej na rozszerzeniu, gdyż średnio $70 \%$ ich eksportu trafia na jednolity rynek europejski, podczas gdy tylko 4\% eksportu dotychczasowych członków stanowią nowe kraje ${ }^{14}$. Dodatkowym czynnikiem sprzyjającym krajom, które przystapiły do Unii, są relatywnie niskie koszty pracy oraz coraz lepsza jakość eksportowanych dóbr, co przyczynia się do znacznego zwiększenia ich konkurencyjności na europejskim rynku.

Również po stronie państw Europy Środkowo-Wschodniej występują pewne obawy, związane z wyzwaniami, jakie niesie ze sobą członkostwo w UE. Zapoczątkowane na początku lat 90. przemiany gospodarcze, oznaczające przede wszystkim zmiany strukturalne w kierunku zmniejszenia udziału zatrudnienia w sektorze rolnym i przemyśle oraz zwiększenia

12 Report of the High Level Group..., op. cit., s. 13.

3 Ibidem, s. 13.

14 Koniunktura gospodarcza..., op. cit., s. 28. 
w sektorze usług, przybliżyły nieco strukturę tych gospodarek do struktury w państwach wysoko rozwiniętych. Nadal jednak struktura zatrudnienia w poszczególnych sektorach odbiega od tej obserwowanej w państwach „starej” Unii. Ogromnym wyzwaniem jest zatem dalsza restrukturyzacja gospodarek w kierunku wspierania rozwoju sektora usług, by promować wzrost, wchłonąć bezrobocie oraz zaspokoić potrzeby społeczne. Sektor usług jest bowiem tym sektorem, który obecnie jest w stanie stworzyć największą liczbę nowych miejsc pracy ${ }^{15}$. Należy jednak zwrócić uwagę na fakt, iż kluczowym dla rozwoju sektora usług jest popyt na konkretne usługi, a to uzależnione jest od przeciętnego poziomu życia i zamożności społeczeństw. Promowanie rozwoju tego sektora, jako najbardziej pracochłonnego, jest więc bardzo ważnym środkiem osiągnięcia wzrostu gospodarczego i wyższego poziomu życia, m.in. poprzez kreowanie nowych miejsc pracy.

Kolejnym wyzwaniem rodzącym określone lęki jest proces doganiania przez nowe państwa poziomu rozwoju osiagniętego w krajach UE-15. Każde rozszerzenie Wspólnoty oznaczało dla wstępujących państw poprawę warunków życia i rozwój gospodarczy, oczywiście pod warunkiem wykorzystania szans, jakie daje proces integracji. Obecne zaawansowanie integracji, wiążące się z funkcjonowaniem UGiW, sprawia jednak, że nowi członkowie muszą podjąć wszelkie działania, aby wypełnić kryteria zbieżności z Maastricht, by móc stać się w przyszłości częścią UGiW i przystapić do strefy Euro. Głównym wyzwaniem dla państw EŚiW jest zatem zapewnienie w długim okresie realnej zbieżności, a jednocześnie osiagnięcie zbieżności nominalnej w perspektywie krótko lub średniookresowej ${ }^{16}$.

Podsumowując dotychczasowe rozważania na temat wpływu rozszerzenia Unii Europejskiej o kraje Europy Środkowej i Wschodniej należy stwierdzić, iż w długookresowej perspektywie będzie ono miało korzystny wpływ na rozwój gospodarczy zarówno państw przyjętych, jak i przyjmujących oraz dla całej poszerzonej Unii. Dzięki wstąpieniu nowych państw dotychczasowi członkowie zyskają większy wzrost gospodarczy, a przewidywane migracje przynajmniej częściowo kompensować będą przyjmującym państwom skutki starzenia się społeczeństw, zaś fakt, iż nie będą one miały charakteru masowego, nie spowoduje niebezpiecznych zawirowań na rynkach pracy dotychczasowych członków. Korzyści osiagną

15 Report of the High Level Group..., op. cit., s. 14.

16 Commission Recommendation on the 2004 update..., op. cit., s. 5. 
także państwa wstępujące, szczególnie ważne będą zaś te w odniesieniu do rynku pracy. Wysokie bezrobocie w większości krajów EŚiW, będące w głównej mierze wynikiem transformacji ich gospodarek, stanowi ogromny problem zarówno dla tych państw, jak i dla całej Unii. Poprawa sytuacji powinna być osiagnięta, przede wszystkim, poprzez odpowiednie działania wewnętrzne i zależy w dużej mierze od stopnia, w jakim polityka gospodarcza kraju sprzyja wykorzystaniu korzyści płynących z członkostwa $^{17}$. Zdecydowanie szybciej jednak może to nastąpić dzięki wspólnym działaniom wszystkich państw członkowskich oraz pomocy ze strony Unii. Poprawa oznacza zmniejszenie stopy bezrobotnych oraz zwiększenie stopy zatrudnienia, jak również podniesienie jakości miejsc pracy i kwalifikacji siły roboczej w taki sposób, aby mogła ona sprostać silnej konkurencji międzynarodowej. Integracja przyczyni się do tego m.in. dzięki wykorzystaniu pomocy z funduszy strukturalnych, utrzymaniu dotychczasowego, wysokiego poziomu inwestycji zagranicznych lub jego zwiększeniu oraz wprowadzeniu zasady swobody przepływu osób.

Powyższe rozważania wymagają zilustrowania danymi statystycznymi, które zobrazują istniejące zróżnicowania w zakresie PKB, zatrudnienia oraz bezrobocia. W efekcie przyjęcia nowych państw nastąpił wzrost liczby ludności zamieszkującej teren Unii o 74588 tys., co stanowi 20\% ludności poszerzonego ugrupowania. W 2004 r. liczba ludności w 15 krajach członkowskich wyniosła 383978 tys., zaś po poszerzeniu zwiększyła się do 458566 tys. ${ }^{18}$ Dzięki wysokiemu, ok. 4\%, wzrostowi gospodarczemu w nowych państwach członkowskich, wyższemu niż średnio w „starej” Unii, nastapił wzrost PKB z poziomu 0,7\% w 2003 r. do 2\% w 2004 r. ${ }^{19}$ Pozostałe wskaźniki dotyczące zatrudnienia i bezrobocia przyczyniają się jednak do pogorszenia średnich wskaźników dla całej Unii, choć niewielki procentowy udział ludności nowych państw sprawia, że nadal sytuacja w tym zakresie determinowana będzie przez sytuację dotychczasowych członków i jej realny wpływ nie będzie zbyt poważny. Zróżnicowane są w tym zakresie zarówno wskaźniki zatrudnienia, aktywności zawodowej oraz struktury zatrudnienia i stopy bezrobocia.

17 Bilans korzyści i kosztów przystapienia Polski do Unii Europejskiej, prezentacja wyników prac polskich ośrodków badawczych, UKIE, Warszawa 2003, s. 97-100.

18 Employment in Europe 2004. Recent Trends and Prospects, European Commission, Directorate-General for Employment and Social Affairs, 2004, Statistical annex, s. 228 .

19 Ibidem, s. 228. 
Wzrost zatrudnienia w obu grupach kształtował się w 2003 r. na takim samym poziomie $0,3 \%$, ale już średni wskaźnik zatrudnienia w nowych krajach członkowskich jest znacznie niższy, aniżeli średnio w „starej” Unii i w 2003 r. kształtował się na poziomie 55,8\%. Oznacza to, że zmniejszył się on w porównaniu z rokiem 1998 o 4,2 pkt proc. (60,0\%), przy czym spadek ten nastąpił głównie wśród mężczyzn - o 5,7 pkt proc. (z 67,3\% do 61,6\%), zaś wśród kobiet wyniósł 2,7 pkt proc. (z 52,9\% do $50,2 \%{ }^{20}$. Najwyższymi wskaźnikami charakteryzowały się; Cypr, Czechy, Estonia i Słowenia, zaś najniższe występowały w Polsce, na Malcie, Węgrzech i Słowacji, co ilustrują dane zawarte w tabeli 7. W znacznym stopniu zmniejszył się w tych krajach wskaźnik zatrudnienia wśród młodzieży (w wieku 15-24 lat), który wyniósł w 2003 r. 24,3\%, wobec $32,4 \%$ w 1998 r. Natomiast zgodnie z europejskimi tendencjami kształtuje się wskaźnik zatrudnienia w grupie starszych pracowników, który zwiększył się w badanym okresie o 0,8 pkt proc. (z 30,9\% do 31,7\%), co wymaga podkreślenia wobec wysokiej ogólnej tendencji spadkowej w tym zakresie.

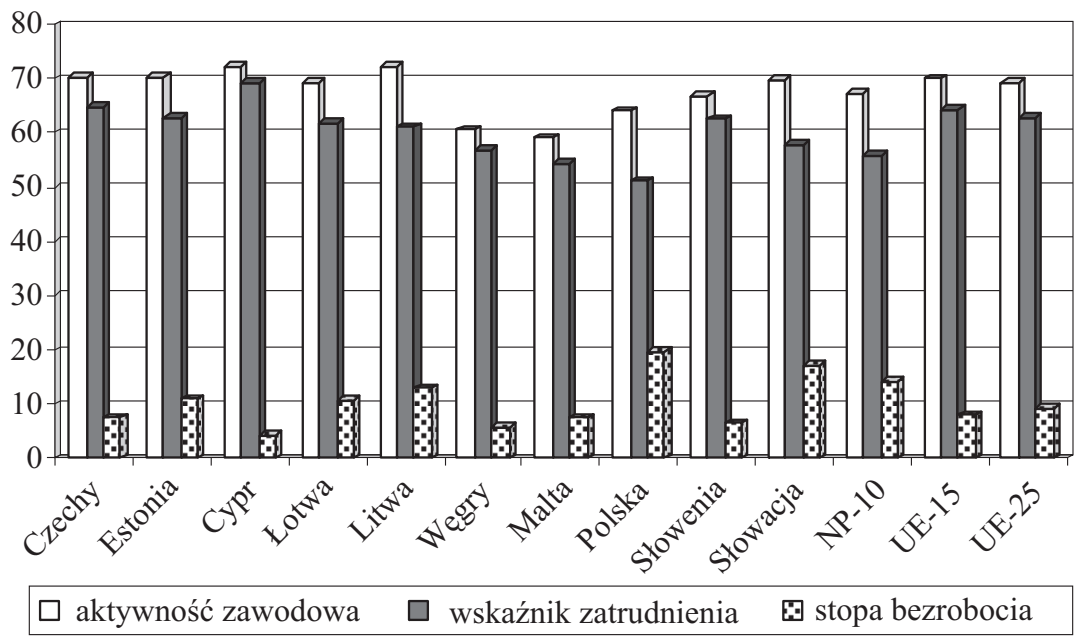

Ryc. 1. Podstawowe dane $\mathrm{z}$ rynku pracy w nowych krajach członkowskich w $2003 \mathrm{r}$.

Źródło: Employment in Europe 2004 i „European Economy” 2004, no. 2, Economic forecasts, Spring 2004, s. 72-93.

20 Employment in Europe 2004, op. cit., s. 39-40. 
Poziom aktywności zawodowej jest również niższy w nowych krajach członkowskich i wyniósł w 2003 r. niewiele ponad 67\%, choć sytuacja jest zróżnicowana w poszczególnych państwach. Najwyższą aktywność zawodową wykazują obywatele: Cypru, Litwy, Czech i Estonii, zaś najniższą obywatele: Malty, Węgier i Polski. Wśród młodej siły roboczej również występuje różnica we wskaźniku aktywności pomiędzy nowymi państwami a „starymi”, która w 2003 r. wyniosła 11,3 pkt proc. (47,2\% w UE-15 wobec $35,9 \%$ w NP-10) ${ }^{21}$.

Analiza zobrazowanych na rycinie 1 danych, dotyczących stóp bezrobocia w poszczególnych państwach, wskazuje na ogromne zróżnicowanie ich wysokości. Najwyższy poziom bezrobocia występował w Polsce, Słowacji oraz na Litwie, gdzie znacznie przekraczał średnią dla 15 członków Unii. Niższy od tej średniej poziom bezrobocia występował zaś na Cyprze, Węgrzech i Słowenii. Średni poziom bezrobocia dla nowych członków wyniósł w 2003 r. 14,3\%, co oznacza, iż było ono znacznie wyższe od bezrobocia w UE-15, gdzie w 2003 r. wyniosło ono 8,1\%.

W nowych państwach, w wyniku przemian strukturalnych nastapiły również zmiany w zakresie struktury zatrudnienia polegające na zmniejszeniu się udziału zatrudnienia w rolnictwie i przemyśle oraz wzroście jego udziału w usługach. Zamieszczona poniżej rycina obrazuje różnice, jakie

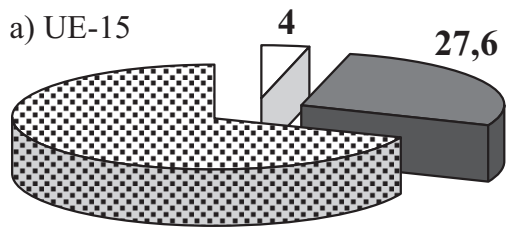

68,3 b) NP-10

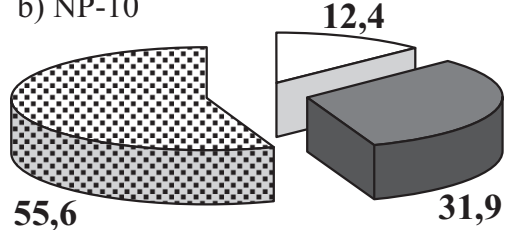

c) UE-25

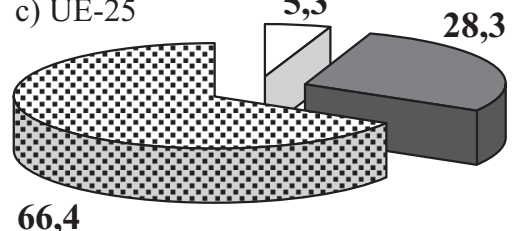

66,4

rolnictwo $\square$ przemysł

Ryc. 2. Struktura zatrudnienia według sektorów gospodarki w $2003 \mathrm{r}$.

Źródło: Employment in Europe 2004 i „European Economy” 2004, no. 2, Economic forecasts, Spring 2004, s. 72-93.

${ }^{21}$ Ibidem, s. 32-33. 
zachodzą w zakresie struktury zatrudnienia w poszczególnych sektorach w UE-15, wśród nowych państw członkowskich oraz łącznie w UE-25.

Występujące rozbieżności dotyczyły głównie zatrudnienia w sektorze usług, gdzie różnica wynosiła prawie 13 pkt proc. (55,6\% wobec $68,3 \%)$ oraz w sektorze rolnym, gdzie różnica wynosi ponad 8 pkt proc. $(12,4 \%$ wobec $4,0 \%$ ). Największe zatrudnienie w rolnictwie charakteryzowało przede wszystkim Litwę (18,7\%) i Polskę (18,2\%), najniższe zaś Maltę (2,5\%), Czechy (4,5\%), Cypr (5,2\%) i Węgry (5,4\%). W sektorze usług największe zatrudnienie występowało na Cyprze $(71,2 \%)$ i Malcie $(67,6 \%)$, zaś najniższe w Polsce (53,2\%), na Litwie (54,1\%) i na Słowenii $(54,4 \%)$.

Powyższe analizy wskazują na olbrzymi dystans, jaki dzieli nowe państwa członkowskie od państw „starej” Unii. W głównej mierze przyczyną niekorzystnych wskaźników jest proces transformacji gospodarczej, jaki miał miejsce w tych krajach. Przemiany zaowocowały zmianą struktury gospodarki, co przede wszystkim oznaczało ogromną redukcję zatrudnienia w nierentownych sektorach wytwarzania, głównie w przemyśle ciężkim i rolnictwie.

Gorsze wskaźniki nowych państw członkowskich nie mająjednak decydującego znaczenia dla wskaźników w poszerzonej Unii. Wskaźnik zatrudnienia zmniejszył się bowiem jedynie o 1,4 pkt proc. (z 64,3\% do $62,9 \%$ ), współczynnik aktywności zawodowej o 0,7 pkt proc. (z $69,9 \%$ do $69,2 \%$ ), zaś poziom bezrobocia o 1 pkt proc. (z 8,1\% do 9,1\%). Potwierdza to wcześniejszą konstatację, iż wpływ rozszerzenia wschodniego w dłuższym okresie, dzięki dużemu potencjałowi wzrostowemu, przyczyni się do rozwoju całej Unii. Jednakże, aby to nastąiło koniecznym jest prowadzenie polityki makroekonomicznej w odpowiednim kształcie zarówno na szczeblu całego ugrupowania, jak i w poszczególnych państwach „starej” i „nowej” Unii Europejskiej.

Zawarte powyżej rozważania dotyczące sytuacji na europejskim rynku pracy stanowią potwierdzenie tezy o konieczności uwzględniania w kreowaniu i prowadzeniu polityki gospodarczej jej wpływu na zatrudnienie i bezrobocie. Obecne zaawansowanie procesów integracji, oznaczające wprowadzenie UGiW stanowi jeszcze jeden argument na rzecz współpracy i koordynowania działań z zakresu rynku pracy. Procesy integracyjne dowiodły także konieczności prowadzenia odpowiedniej polityki zatrudnienia i spraw społecznych, choć nie był to od początku powstania Wspólnot główny problem. Należy stwierdzić, iż powyższa analiza stanowić może istotny element dla wskazania pożądanych kierunków rozwoju polskiej polityki makroekonomicznej. 
W opracowaniu wskazano na zmiany, jakie zaszły w gospodarce wspólnotowej oraz w gospodarkach poszczególnych państw członkowskich. Jednym z głównych osiagnięć przekształceń strukturalnych, jakie dokonały się w latach 80 . i 90., było wzmocnienie odporności rynku pracy na wahania koniunkturalne. Podczas gdy spadek tempa wzrostu gospodarczego w I połowie lat 80. i 90. pociagnął za sobą znaczący spadek zatrudnienia oraz wzrost bezrobocia (z 7\% w 1981 r. do 9,4\% w 1985 r. i z 7,3\% w 1990 r. do 10,5\% w 1994 r.), to już słaba koniunktura w latach 2001-2003 oznaczała jedynie zmniejszenie tempa wzrostu zatrudnienia oraz nieznaczny wzrost bezrobocia (z 7,4\% w 2001 r. do 8,1\% w 2003 r.). Istotną rolę $\mathrm{w}$ tym procesie odegrały przekształcenia strukturalne $\mathrm{w}$ gospodarce, polegające na ograniczeniu zatrudnienia w sektorze rolnym i przemysłowym na rzecz zwiększenia udziału zatrudnienia w usługach, większa elastyczność rynku pracy oraz poprawa jakości kształcenia, kształcenie zawodowe i ustawiczne. Wykorzystanie elastycznych form zatrudnienia pozwoliło na dostosowanie zapotrzebowania na siłę roboczą do warunków ekonomicznych oraz zwiększenie wskaźnika zatrudnienia i aktywności zawodowej poprzez możliwość łączenia pracy zawodowej z życiem rodzinnym (zwłaszcza dla kobiet) oraz podnoszeniem kwalifikacji.

Poważnym problemem, z jakim boryka się Unia Europejska, jest natomiast proces starzenia się społeczeństwa. Zmniejszenie tempa przyrostu naturalnego oraz wydłużenie czasu życia sprawia, że w nadchodzących latach dochody narodowe państw członkowskich tworzone będą przez coraz mniejsze i starsze zbiorowości pracujących. Oznacza to także poważne problemy dla systemów emerytalnych, zabezpieczenia zdrowotnego oraz opieki nad osobami starszymi. W tym zakresie szansa, a nie zagrożeniem, dla „starej” Unii jest napływ (głównie młodej) siły roboczej z nowych państw członkowskich, która choć częściowo zrekompensuje proces starzenia się. Należy jednak zaznaczyć, że również w tych krajach obserwuje się już wyraźne oznaki tego procesu.

Kolejne rozszerzenia Wspólnoty wiązały się z określonymi skutkami zarówno dla państw wstępujących, jak i przyjmujących. Należy stwierdzić, iż poszerzanie granic Wspólnoty niosło korzyści dla obu stron, choć ich skala w dużej mierze zależała od poziomu rozwoju krajów przystępujących, dystansu, jaki dzielił je od państw przyjmujących oraz kształtu wewnętrznej polityki makroekonomicznej. Rozszerzenie Unii o kraje Europy Środkowej i Wschodniej jest wydarzeniem precedensowym, gdyż po raz pierwszy wstąpiła tak liczna grupa państw. Ich poziom rozwoju jest znacznie niższy od unijnej średniej, a dystans, jaki mają do pokonania 
ogromny, ale szansę stanowi w tym zakresie wysoki wzrost gospodarczy, jaki obecnie osiaggają oraz odpowiedni kształt polityki gospodarczej, który pozwoli wykorzystać płynące z członkostwa w Unii Europejskiej szanse.

Wykorzystanie szans płynących z obecnego poszerzenia jest głównym zadaniem zarówno państw „starej”, jak i nowej Unii. Wspólne działania i polityki zmierzać powinny do osiagnięcia ustalonego w Lizbonie celu strategicznego Unii, a mianowicie wykorzystania zachodzących zmian technologicznych na rzecz uzyskania przez gospodarkę europejską maksymalnej konkurencyjności i szybkiego tempa wzrostu tak, aby stworzyć dogodne warunki do pełnego zatrudnienia i zwiększenia stopnia regionalnej spójności w Unii Europejskiej.

\section{Summary}

The EU enlargement involving the Central and Eastern Europe states set a precedent, as never before in the history of European integration were so many states admitted. On May 1, 2004 the European Fifteen was joined by ten new states thus forming a group of 25 states. The objective of this paper is to present the desirable direction for Polish macroeconomic policy on the basis of the experience provided by integrationist processes, with particular emphasis on the experience of Ireland, Greece, Portugal and Spain. The main task of both the 'old' and the 'new' Union is to take advantage of the opportunities that result from this enlargement. Joint activities and policies should aim at the achievement of the EU strategic aim, established in Lisbon, i.e. at taking advantage of the technological change to achieve the maximum competitiveness and rapid growth pace of the EU economy so that appropriate conditions are created to provide full employment and increase the extent of regional cohesion in the EU. 